\title{
BMI and WC cut offs for the risk of comorbidities of obesity in a population in Indonesia
}

Rachmad Soegih

\begin{abstract}
Abstrak
Pada dekade terakhir ini para dokter dan penanggung jawab bidang kesehatan mulai menyadari bahwa kegemukan dan berat badan berlebih mempunyai dampak kesehatan yang merugikan seperti timbulnya penyakit diabetes, penyakit jantung pembuluh darah dan penyakit penyerta lain yang lebih dikenal sebagai komorbiditas. Pengukuran tingkat kegemukan yang sudah diterima secara luas adalah yang menggunakan indeks masa tubuh (IMT) dan ukuran lingkar pinggang (LP). Atas dasar itu perlu kiranya Indonesia mempunyai nilai IMT dan LP sendiri, untuk faktor risiko komorbiditas. Penelitian cross sectional ini mencakup 6318 subyek yang terdiri dari 5216 laki-laki (82,6\%) dan 1102 wanita (17,6\%). Faktor risiko utama komorbiditas, baik pada laki-laki dan wanita adalah peninggian kolesterol dan trigliserida. Resiko timbulnya komorbiditas mulai meningkat pada IMT $24,38 \mathrm{~kg} / \mathrm{m}^{2}$ dan lingkar pinggang (LP) $86,25 \mathrm{~cm}$ untuk kadar gula darah puasa dan IMT 24,91 kg/m² dan LP 89,25 cm untuk kadar triglycerida. (Med J Indones 2004; 13: 241-5)
\end{abstract}

\begin{abstract}
Over the last few years health care providers have become more aware of the consecquences of obesity as well as the comorbidities of obesity. The body mass index (BMI) and waist circumference (WC) became universally accepted measures to determine the degree of overweight. it is necessary to have cut off points for BMI and WC for the risk factors of the comorbidities of obesity in Indonesia. This study has a cross sectional design with a total of 6318 subjects, that comprised of 5216 males (82.6\%) and 1102 females (17.6\%). The highest percentage of comorbidities both in males and females were high cholesterol and triglyceride level. The risks of comorbidities were increased at BMI $24.38 \mathrm{~kg} / \mathrm{m}^{2}$ and WC $86.25 \mathrm{~cm}$ for fasting blood glucose and BMI $24.91 \mathrm{~kg} / \mathrm{m}^{2}$ and WC $89.25 \mathrm{~cm}$ for triglyceride level. (Med J Indones 2004; 13: 241-5)
\end{abstract}

Keywords: plasma glucose level, serum lipid profile

Obesity is a world wide problem, affecting both developed and developing countries including Indonesia. In developed countries the prevalence is high and increasing. In Indonesia, a study by department of health in 26 cities from 1996-1997 found that the prevalence of overweight (body mass index/BMI 25.1-30) and obesity (BMI > 30.0) in adult (19-65 year old) were 17.5 and $4.7 \%$, respectively.

The epidemiology of obesity has for many years been difficult to study, because many countries had their own specific criteria for the classification of different degrees of overweight. However, the body mass index (weight/height) became a universally accepted measure

Department of Nutrition, Faculty of Medicine, University of Indonesia, Jakarta, Indonesia to determine the degree of overweight, and now identical cut points are recommended. The most recent classification of overweight in adults by the WHO is depicted in Table 1.

Table 1. Recent classification of overweigh in adults (WHO)

\begin{tabular}{lll}
\hline \multicolumn{1}{c}{ Classification } & BMI $(\mathrm{kg} / \mathrm{m} 2)$ & Associated health risk \\
\hline Underweight & $<18.5$ & $\begin{array}{l}\text { Low (but risk of other } \\
\text { clinical poblems } \\
\text { increased) } \\
\text { Average }\end{array}$ \\
$\begin{array}{l}\text { Normal range } \\
\text { Overweight (25.0 } \\
\text { or higher) }\end{array}$ & $18.5-24.9$ & Increased \\
$\begin{array}{l}\text { Pre-obese } \\
\text { Obese class I }\end{array}$ & $30.0-34.9$ & $\begin{array}{l}\text { Moderately increased } \\
\text { Obese class II }\end{array}$ \\
$\begin{array}{l}\text { Obese class III } \\
40.0-39.9\end{array}$ & $\begin{array}{l}\text { Severely increased } \\
\text { Very severely increased }\end{array}$ \\
\hline
\end{tabular}


Obesity is related to several comorbidities. Recently investigators ${ }^{2,3}$ and policy making organizations $s^{4,5}$ have questioned whether the BMI cut points for obesity $\left(30 \mathrm{~kg} / \mathrm{m}^{2}\right)$ and overweight $\left(25 \mathrm{~kg} / \mathrm{m}^{2}\right)$ that are currently used in the United States and in European countries are appropriate for the population in Asian countries as well as in Indonesia. Furthermore, data about cut off points for the risk factors of comorbidities of obesity in Indonesia are not readily available.

The purpose of this study was to calculate the BMI and WC cut offs for the risk factors that play a role in the development of the comorbidities in overweight and obese people.

\section{METHODS}

This study was cross sectional in design, using a selected population. In total, 6.318 subjects who participated in the general health check up for workers of different companies were enrolled in this study. The level of workers ranged from blue collar to white collar, as well as excecutive level. The companies were spread in different provinces of Indonesia.

- The survey was conducted between early 2003 to mid 2004

- The antropometric indices were: height (using microtoise in $\mathrm{cm}$ ) weight (using digital balance with the accuracy of $0.1 \mathrm{~kg}$, measured without shoes and the subject only wear tight clothing), and waist circumference (WC)

- Biochemical analysis: fasting blood glucose (FBG) was measured by using glucose oxidase method. Serum lipid profile including total cholesterol, triglyceride, high density lipoprotein and low density lipoprotein were measured using automatic biochemical instrument.

BMI and WC cut offs for the risk of comorbidities in obese individuals were calculated using receiver operating curve (ROC) analysis.

\section{RESULT}

- A total of 6,318 subject comprised 5,216 males $(82.6 \%)$ and 1,102 females $(17.6 \%)$ was enrolled in the study. The age mean \pm SD of the sample was $42.41 \pm 9.86$, with the range of $20-85$ years. ${ }^{8}$
The distribution of subjects by age and gender were seen in Tabel 2.

Table 2. The Distribution of subjects by age and gender

\begin{tabular}{lrrrr}
\hline \multirow{2}{*}{ Age (year) } & \multicolumn{2}{c}{ M a l e } & \multicolumn{2}{c}{ F e m a l e } \\
\cline { 2 - 5 } & \multicolumn{1}{c}{$\mathrm{n}$} & \multicolumn{1}{c}{$\%$} & \multicolumn{1}{c}{$\mathrm{n}$} & \multicolumn{1}{c}{$\%$} \\
\hline $20-29$ & 155 & 2.98 & 107 & 9.62 \\
$30-40$ & 2036 & 39.11 & 386 & 34.71 \\
$41-55$ & 2413 & 45.95 & 385 & 34.62 \\
$>55$ & 267 & 5.13 & 229 & 20.59 \\
Unknown & 335 & 6.43 & 5 & 0.45 \\
\hline Total & 5206 & 100.0 & 1112 & 100.0 \\
\hline
\end{tabular}

The highest percentages of age both in males and females were the age group of 30-55 years (male $85.06 \%$ and female $69.33 \%$ ).

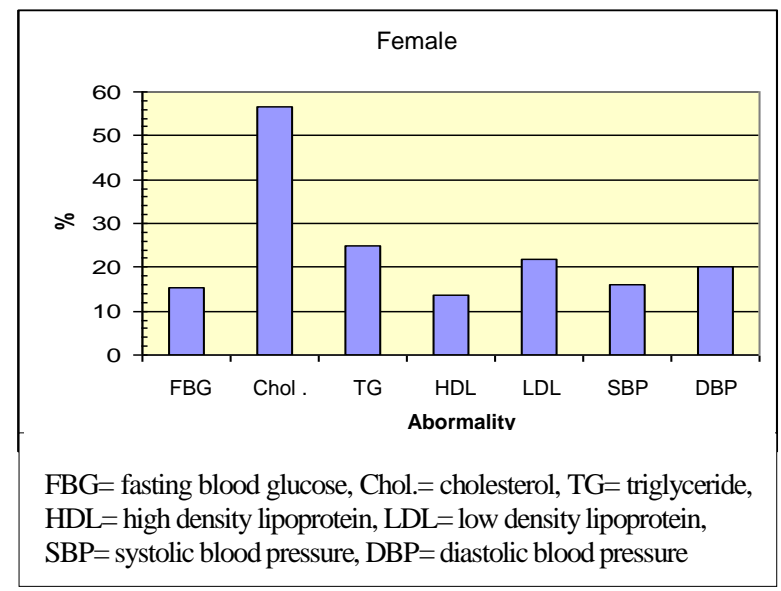

Figure 1. Prevalence of females with BMI > 23 having abnormalities that were related to comorbidities of obesity

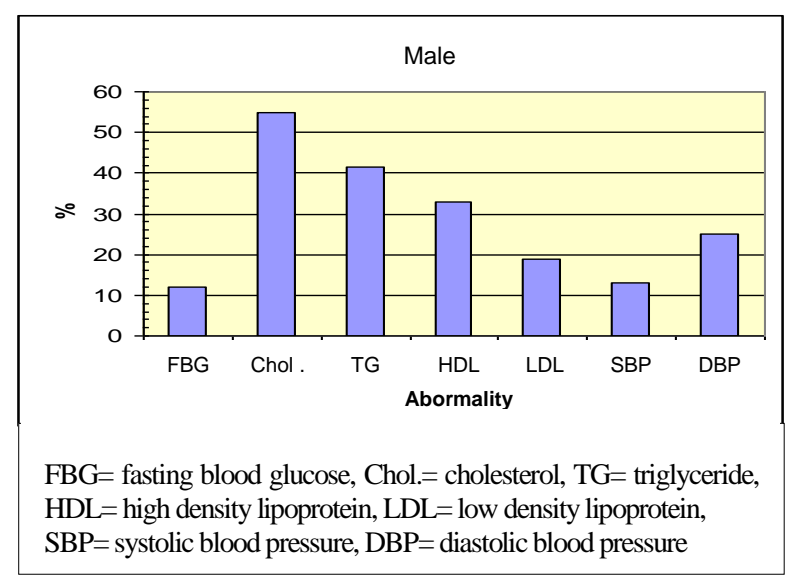

Figure 2. Prevalence of males with $B M I \geq 23$ having abnormalities that were related to comorbidities of obesity 


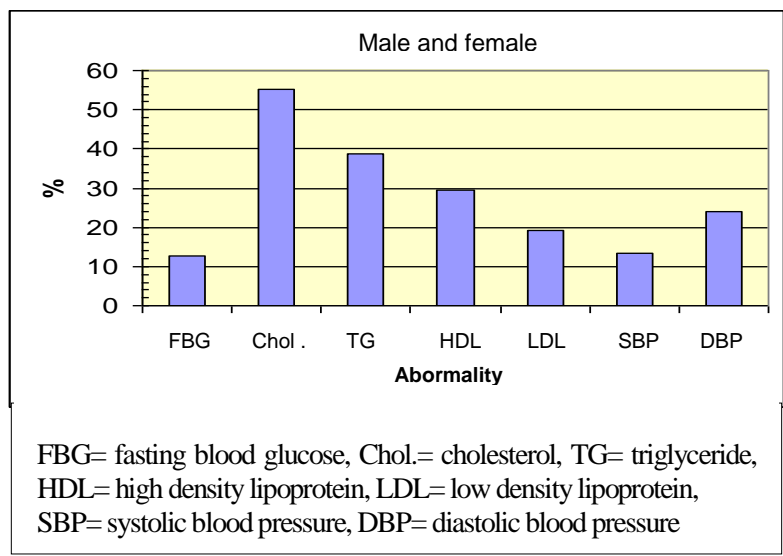

Figure 3. Prevalence of females and males with $B M I \geq 23$ having abnormalities that were related to comorbidities of obesity

Figure 1, 2, 3 showed the prevalence of abnormalities that were related to comorbidities of obesity.

Table 3 and 4 showed that in females, FBG had the highest sensitivity and specificity, with BMI cut off 24.67 and WC cut off 85.50.

Table 5 and 6 showed that in males triglyseride was the most sensitive parameter when we used BMI (BMI cut off 24.54), while FBG was the most sensitive when we used WC (WC cut off 89.25).

Table 3. The BMI cut offs for comorbidity related abnormalities in females

\begin{tabular}{lcccc}
\hline & $\begin{array}{c}\text { BMI } \\
\text { Cut off }\end{array}$ & Sensitivity & Specificity & $\begin{array}{c}\text { Sens. X } \\
\text { Spec }\end{array}$ \\
\hline $\begin{array}{l}\text { FBG } \\
(\geq 110 \mathrm{mg} / \mathrm{dl})\end{array}$ & 24.67 & 0.72 & 0.62 & 0.44 \\
$\begin{array}{l}\text { SBP } \\
(>140 \mathrm{mmHg})\end{array}$ & 24.75 & 0.69 & 0.62 & 0.42 \\
$\begin{array}{l}\text { TG } \\
(\geq 150 \mathrm{mg} / \mathrm{dl})\end{array}$ & 23.95 & 0.71 & 0.57 & 0.40 \\
$\begin{array}{l}\text { HDL cholesterol } \\
(\leq 40 \mathrm{mg} / \mathrm{dl})\end{array}$ & 24.03 & 0.72 & 0.54 & 0.39 \\
$\begin{array}{l}\text { DBP } \\
(\geq 90 \mathrm{mmHg})\end{array}$ & 24.32 & 0.65 & 0.58 & 0.37 \\
$\begin{array}{l}\text { Total cholesterol } \\
(\geq 200 \mathrm{mg} / \mathrm{dl})\end{array}$ & 23.51 & 0.61 & 0.54 & 0.33 \\
$\begin{array}{l}\text { LDL cholesterol } \\
(\geq 160 \mathrm{mg} / \mathrm{dl})\end{array}$ & 23.91 & 0.62 & 0.52 & 0.32 \\
\hline
\end{tabular}

$\mathrm{FBG}=$ fasting blood glucose, $\mathrm{SBP}=$ systolic blood pressure, $\mathrm{TG}=$ triglyceride, $\mathrm{HDL}=$ high density lipoprotein, $\mathrm{DBP}=$ diastolic blood pressure, $\mathrm{LDL}=$ low density lipoprotein
Table 4. Waist circumference (WC) cut offs for comorbidity related abnormalities in females

\begin{tabular}{lcccc}
\hline & $\begin{array}{c}\text { WC } \\
\text { Cut off }\end{array}$ & Sensitivity & Specificity & $\begin{array}{c}\text { Sens. X } \\
\text { Spec }\end{array}$ \\
\hline $\begin{array}{l}\text { FBG } \\
(\geq 110 \mathrm{mg} / \mathrm{dl})\end{array}$ & 85.50 & 0.66 & 0.73 & 0.48 \\
$\begin{array}{l}\text { TG } \\
(\geq 150 \mathrm{mg} / \mathrm{dl})\end{array}$ & 80.50 & 0.73 & 0.58 & 0.42 \\
$\begin{array}{l}\text { SBP } \\
(>140 \mathrm{mmHg})\end{array}$ & 80.50 & 0.78 & 0.53 & 0.41 \\
$\begin{array}{l}\text { HDL cholesterol } \\
(\leq 40 \mathrm{mg} / \mathrm{dl})\end{array}$ & 81.50 & 0.69 & 0.58 & 0.40 \\
$\begin{array}{l}\text { DBP } \\
(\geq 90 \mathrm{mmHg})\end{array}$ & 80.50 & 0.71 & 0.52 & 0.37 \\
$\begin{array}{l}\text { Total cholesterol } \\
(\geq 200 \mathrm{mg} / \mathrm{dl})\end{array}$ & 79.50 & 0.62 & 0.58 & 0.36 \\
$\begin{array}{l}\text { LDL cholesterol } \\
(\geq 160 \mathrm{mg} / \mathrm{dl})\end{array}$ & 81.50 & 0.61 & 0.58 & 0.35 \\
\hline
\end{tabular}

$\mathrm{FBG}=$ fasting blood glucose, $\mathrm{TG}=$ triglyceride, $\mathrm{SBP}=$ systolic blood pressure, $\mathrm{HDL}=$ high density lipoprotein, $\mathrm{DBP}=$ diastolic blood pressure, $\mathrm{LDL}=$ low density lipoprotein

Table 5. Body mass index (BMI) cut offs for comorbidity related abnormalities in males

\begin{tabular}{lcccc}
\hline & $\begin{array}{c}\text { BMI } \\
\text { Cut off }\end{array}$ & Sensitivity & Specificity & $\begin{array}{c}\text { Sens. X } \\
\text { Spec }\end{array}$ \\
\hline TG & 24.54 & 0.66 & 0.58 & 0.38 \\
FBG & 25.34 & 0.60 & 0.59 & 0.36 \\
SBP & 25.00 & 0.64 & 0.55 & 0.35 \\
$\begin{array}{l}\text { DBP } \\
\text { HDL } \\
\text { cholesterol }\end{array}$ & 24.44 & 0.65 & 0.52 & 0.34 \\
$\begin{array}{l}\text { Total } \\
\text { cholesterol }\end{array}$ & 24.61 & 0.54 & 0.62 & 0.34 \\
$\begin{array}{l}\text { LDL } \\
\text { cholesterol }\end{array}$ & 24.54 & 0.61 & 0.50 & 0.30 \\
\hline
\end{tabular}

$\mathrm{TG}=$ triglyceride, $\mathrm{FBG}=$ fasting blood glucose, $\mathrm{SBP}=$ systolic blood pressure, $\mathrm{DBP}=$ diastolic blood pressure, $\mathrm{HDL}=$ high density lipoprotein, $\mathrm{LDL}=$ low density lipoprotein 
Table 6. Waist circumference (WC) cut offs for comorbidity related abnormalities in males

\begin{tabular}{lcccc}
\hline & $\begin{array}{c}\text { WC } \\
\text { Cut off }\end{array}$ & Sensitivity & Specificity & $\begin{array}{c}\text { Sens. X } \\
\text { Spec }\end{array}$ \\
\hline FBG & 89.25 & 0.62 & 0.63 & 0.39 \\
TG & 87.45 & 0.64 & 0.60 & 0.38 \\
SBP & 87.75 & 0.70 & 0.52 & 0.37 \\
HDL & & & & \\
cholesterol & 87.75 & 0.61 & 0.56 & 0.34 \\
DBP & 87.75 & 0.63 & 0.54 & 0.34 \\
$\begin{array}{l}\text { Total } \\
\text { cholesterol }\end{array}$ & 86.35 & 0.60 & 0.54 & 0.33 \\
$\begin{array}{l}\text { LDL } \\
\text { cholesterol }\end{array}$ & 86.85 & 0.63 & 0.49 & 0.31 \\
\hline
\end{tabular}

$\mathrm{FBG}=$ fasting blood glucose, $\mathrm{TG}=$ triglyceride, $\mathrm{SBP}=$ systolic blood pressure, $\mathrm{HDL}=$ high density lipoprotein, $\mathrm{DBP}=$ diastolic blood pressure, $\mathrm{LDL}=$ low density lipoprotein

Table 7. Body mass index (BMI) cut offs for comorbidity related abnormalities in males and females

\begin{tabular}{lcccc}
\hline & $\begin{array}{c}\text { BMI } \\
\text { Cut off }\end{array}$ & Sensitivity & Specificity & $\begin{array}{c}\text { Sens. X } \\
\text { Spec }\end{array}$ \\
\hline TG & 24.38 & 0.68 & 0.57 & 0.39 \\
FBG & 24.91 & 0.66 & 0.56 & 0.37 \\
SBP & 24.99 & 0.64 & 0.56 & 0.36 \\
DBP & 24.44 & 0.65 & 0.53 & 0.35 \\
$\begin{array}{l}\text { HDL } \\
\text { cholesterol }\end{array}$ & 25.37 & 0.55 & 0.62 & 0.34 \\
$\begin{array}{l}\text { Total } \\
\text { cholesterol }\end{array}$ & 24.51 & 0.57 & 0.56 & 0.32 \\
$\begin{array}{l}\text { LDL } \\
\text { cholesterol }\end{array}$ & 24.56 & 0.59 & 0.52 & 0.31 \\
\hline
\end{tabular}

$\mathrm{TG}=$ triglyceride, $\mathrm{FBG}=$ fasting blood glucose, $\mathrm{SBP}=$ systolic blood pressure, $\mathrm{DBP}=$ diastolic blood pressure, $\mathrm{HDL}=$ high density lipoprotein, $\mathrm{LDL}=$ low density lipoprotein

Table 8. Waist circumference (WC) cut offs for comorbidity related abnormalities in males and females

\begin{tabular}{lcccc}
\hline & $\begin{array}{c}\text { WC } \\
\text { Cut off }\end{array}$ & Sensitivity & Specificity & $\begin{array}{c}\text { Sens. X } \\
\text { Spec }\end{array}$ \\
\hline FBG & 86.25 & 0.65 & 0.61 & 0.39 \\
TG & 89.25 & 0.60 & 0.66 & 0.39 \\
SBP & 87.75 & 0.67 & 0.56 & 0.37 \\
$\begin{array}{l}\text { HDL } \\
\text { cholesterol }\end{array}$ & 86.60 & 0.64 & 0.57 & 0.36 \\
$\begin{array}{l}\text { DBP } \\
\begin{array}{l}\text { Total } \\
\text { cholesterol }\end{array}\end{array}$ & 86.75 & 0.64 & 0.54 & 0.35 \\
$\begin{array}{l}\text { LDL } \\
\text { cholesterol }\end{array}$ & 86.25 & 0.56 & 0.58 & 0.33 \\
\hline
\end{tabular}

$\mathrm{FBG}=$ fasting blood glucose, $\mathrm{TG}=$ triglyceride, $\mathrm{SBP}=$ systolic blood pressure, $\mathrm{HDL}=$ high density lipoprotein, $\mathrm{DBP}=$ diastolic blood pressure, $\mathrm{LDL}=$ low density lipoprotein
Table 7 and 8 showed that in both males and females triglyceride was the most sensitive parameter when we used BMI (BMI cut off 24.38), while FBG was the most sensitive when we used WC (WC cut off 86.25). The results indicated that for the population in this study, BMI cut off 24.38 and WC cut off 86.25 were very important, as the comorbidities of obesity started to appear.

\section{DISCUSSION}

The comorbidities of obesity and overweight will appear if there were abnormalities of the serum fasting blood glucose $(\geq 110 \mathrm{mg} / \mathrm{dl})$, total cholesterol $(\geq 200 \mathrm{mg} / \mathrm{dl}), \mathrm{HDL}$ cholesterol $(\leq 40 \mathrm{mg} / \mathrm{dl}), \mathrm{LDL}$ cholesterol $(\geq 160 \mathrm{mg} / \mathrm{dl})$, and triglyceride $(\geq 150 \mathrm{mg} / \mathrm{dl})$ level, in addition to high systolic $(\geq 140 \mathrm{mmHg})$ and diastolic blood pressure $(\geq 90 \mathrm{mmHg})$. These abnormalities are risk factors for comorbidities of obesity.

The purpose of calculating BMI cut offs and WC cut offs for the risk factors of comorbidities of obesity (and overweight) for Indonesian were :

1. BMI cut off point should be based on risk factors rather than body fat.

2. There was insufficient evidences on associations between BMI and mortality.

Table 3 showed that the prevalence of males and females with $\mathrm{BMI} \geq 23$ having high cholesterol and triglyceride level was $55.1 \%$ and $38.6 \%$, respectively. This fact was not in line with the food pattern in Indonesia, where the major calorie source came from carbohydrate (rice 55-70\%). We estimated that the high triglyceride level would be prominent. However, the level of cholesterol was also increased.

This fact might be due to the shifting of eating habit to westernized food pattern. Furthermore, the prevalence of high blood pressure especially the diastolic blood pressure was rather high $(24.1 \%)$.

Despite the need for a uniform criteria for risk factors of comorbidities of obesity, arguments can be made for the choice of different BMI cut points among ethnic groups that are used as public health action points for different countries. ${ }^{6}$ The level of BMI at which individuals within a nation are the target for public health or medical attention are influenced by issues that are different from those that determine the 
criteria of the comorbidities. These include issues such as the population specific distribution of BMI and obesity-associated-comorbidity, as well as the National Resources.

The BMI range that is associated with the largest population attributable risk of a certain comorbidity of obesity may be considerably lower than the BMI range associated with the largest relative risk of the comorbidity, due to the distribution of BMI in the population. For instance, the prevalence of BMI over 30 is so low in many Asian countries, that a health program that targets only individuals with BMI above that level will have little impact.

On the other hand there was an evidence that the population distribution of BMI was shifting to improve the range to the so called within "normal" range (BMI $18.5-25 \mathrm{~kg} / \mathrm{m}^{2}$ ), while at the same time the prevalence of a comorbidity such as diabetes was increasing. This fact might be a reason for the Government to target public health resources toward individuals with BMI in the upper end of the normal range. ${ }^{7}$

There were evidences from certain populations ${ }^{8,9}$ as well as Asian population ${ }^{10,11}$ that the risk of diabetes increased with increasing BMI, and there was a reason to lower the threshold from BMI $18.5-25 \mathrm{~kg} / \mathrm{m}^{2}$ to BMI $18.5-23 \mathrm{~kg} / \mathrm{m}^{2}$. Furthermore, changes in dietary and physical activity behavior, have resulted in a global epidemic of obesity.

In conclusions, BMI cut offs $24.38 \mathrm{~kg} / \mathrm{m}^{2}$ and 24.91 $\mathrm{kg} / \mathrm{m}^{2}$, and WC cut offs of $86.25 \mathrm{~cm}$ and $89.25 \mathrm{~cm}$ increased the risk of having high fasting blood glucose, and triglyseride level, respectively. This fact might be related to the food pattern of the most population in Indonesia where the main source of the energy came from rice.

\section{Acknowledgements}

The author would like to thank Mr. Andi Wijaya, and Mr. Tommy Heryanto from Prodia Laboratory for their support, during the survey and data analysis.

\section{REFERENCES}

1. World health organization. Obesity preventing and management the global epidemic. WHO: Geneve; 2000.

2. Moon O, Kim N, Jang S, Yoon T, Kim S. The relationship between body mass index and the prevalence of obesityrelated diseases based on the 1995 National Health Interview Survey in Korea. Obes Rev 2002; 3: 191-6.

3. Deurenberg P, Yap M, van Staveren W. Body mass index and percent body fat: a meta analysis among different ethnic groups. Int J Obes Relat Metab Disord 1998; 22: 1164-71.

4. International Diabetes Institute. The Asia-Pacific perspective: redefining obesity and its treatment. World Health Organization: Geneva; 2000.

5. World Health Organization. Report of a WHO expert consultation on appropriate BMI for Asian populations and its implications for policy and intervention strategies. WHO: Geneva; 2002.

6. World Health Organization Expert Committee. Physical status: the use and interpretation of anthropometry. World Health Organization: Geneva; 1995.

7. Stevens J. Ethnic specific cutpoints for obesity as country specific guidelines for action. Int J Obes 2003; 27: 287-8.

8. Hu F, Manson J, Stampfer M. Diet, lifestyle, and the risk of type 2 diabetes mellitus in women. N Engl J Med 2001; 345: 790-7.

9. Chan J, Rimm E, Colditz G, Stampfer M, Willitt W. Obesity, fat distribution, and weight gain as risk factors for clinical diabetes in men. Diabetes Care 1994; 17: 961-9.

10. Ko G, Chan J, Cockram C, Woo J. Prediction of hypertension, diabetes, dyslipidemia or albuminuria using simple anthropometric indexes in Hong Kong Chinese. Int J Obes Relat Metab Disord 1999; 23: 1136-42.

11. Jia W, Xiang K, Chen L, Lu J, Wu Y. Epidemiological study on obesity and its comorbidities in urban Chinese older than 20 year Shanghai, China. Obes Rev 2002; 3: 157-65. 
